IRA-International Journal of Education \& Multidisciplinary Studies ISSN 2455-2526; Vol.05, Issue 02 (2016)

Pg. no. 76-85

Institute of Research Advances

http://research-advances.org/index.php/IJEMS

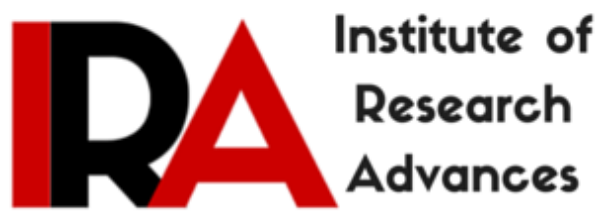

\title{
The Student Teachers' Experiences during Teaching Practice and Its Impact on their Perception of the Teaching Profession
}

\author{
Dr. Rachel Koross \\ University of Eldoret, School of Education, \\ Department of Curriculum and Instruction, \\ P.O Box 7892-30100. Eldoret, Kenya.
}

Type of Review: Peer Reviewed.

DOI: http://dx.doi.org/10.21013/jems.v5.n2.p3

\section{How to cite this paper:}

Koross, R. (2016). The Student Teachers' Experiences during Teaching Practice and Its Impact on their Perception of the Teaching Profession. IRA International Journal of Education and Multidisciplinary Studies (ISSN 2455-2526), 5(2), 76-85.

doi:http://dx.doi.org/10.21013/jems.v5.n2.p3

(C) Institute of Research Advances

\section{(cc) BY-NC}

This work is licensed under a Creative Commons Attribution-Non Commercial 4.0 International License subject to proper citation to the publication source of the work.

Disclaimer: The scholarly papers as reviewed and published by the Institute of Research Advances (IRA) are the views and opinions of their respective authors and are not the views or opinions of the IRA. The IRA disclaims of any harm or loss caused due to the published content to any party. 


\begin{abstract}
Teaching practice is an integral component of teacher training in Kenyan universities. Teaching practice in Kenyan universities is organized in the schools of education and is mandatory for all students who pursue education. Students go out to real classroom environment for a whole term (approximately 14 weeks).This activity grants student teachers experiences in the real teaching and learning environment. This paper looks at the students' experiences and its impact on their perception of the teaching profession and also assesses the challenges that students encounter while in the schools that they are attached for teaching practice. The sample was drawn from third year student teachers from the University of Eldoret who had done teaching practice. A survey design was used and a quantitative questionnaire was administered to 100 student teachers. The findings of this research indicate that students' experiences had an impact on their perception of the teaching profession and they did experience challenges while on teaching practice. Based on the findings of this study recommendations are given on how to improve students' perspective and challenges.
\end{abstract}

Key words: Student teachers, experiences, teaching practice, Perception, teaching profession

\title{
1. Introduction
}

Teaching practice is an exercise that is carried out by all schools of education in Kenyan universities and the rest of the world. Teaching practice in the 21st century is considered to be one of the most influential aspects of pre-service teacher education (Haigh 2001). Ezewu et al. (1994), indicate that the term "teaching practice" has been accepted almost universally and uncritically by all concerned with the preparation of teachers and its use has embraced all the learning experiences of student teachers in schools. This concept has been handed down from the earliest days of the development of training colleges. Today, it is considered a necessary and valuable activity for the qualifications of an envisaged teacher thus it needs to be conducted effectively. It is a requirement in the teacher education programme in Kenya in that a student cannot graduate without having gone through teaching practice process. Moreover, with increased demands being placed on teachers to meet the needs of diverse students and to design classrooms and use methods of teaching that are learner centred, the world of teaching has become more complex. Hence universities and schools of education are exploring new approaches to teacher education. As most of the influential pedagogies in teacher education are those relating to supervised field experience such as teaching practice, there is need to study the challenges and possible solutions to these challenges that student teachers may encounter while in teaching practice and the impact of the experiences that they get on the teaching profession. There is need also to establish ways to assist preservice teachers in the transition from the role of students to the role of beginning teachers. The experience has been that the actual practice of using field experience varies greatly depending largely on the amount of support that is provided to student teachers. However, in as much as teaching practice is important in preparing pre-service teachers, it is not an easy task to undertake. Broadbent (1998) states that teaching practice is the most challenging experience for student teachers in the teacher education programme. In view of this challenging and problematic nature of teaching practice, this study examines the student teachers' experiences during teaching practice and its impact on their perception of the teaching profession.

\subsection{Background}

According to Cohen et al. (1996), since the establishment of training colleges in the middle and late $19^{\text {th }}$ century, teaching practice in one form or another has remained an unchallenged, essential element in the preparation of generations of teachers. In Kenya teaching practice is considered as an important component of becoming a teacher. It has been used in teacher training since independence. Koko (2002) remarks that, teaching practice in most educational institutions is the expected terminal behaviour of a student teacher who is going through professional course in education. In Kenyan universities, it is done 
in an organized program whereby students are posted to schools and will teach for a term (13-14 weeks) with the guide of the cooperating teachers and school management. The teaching of skills which is done in teaching practice is not something new in the African education system. In the traditional African society skills such as hunting, singing, reciting, carving and drawing were learnt through practice. These traditional practices are not dissimilar to those typifying our current approaches to student teaching. Samuel (2010) refers to teaching practice as far back as the first model of teacher education, the master apprenticeship model, in which the novice teacher learns best through behavioural modeling, through imitating the expert teacher. Menter (1989:460) notes that there has been a shift in the literature from the concept of teaching practice (associated with an apprenticeship model) to the concept of field/school experience (associated with an experiential model). Lave \&Wenger (1991) point out that however way it may be envisaged, the notion of teaching practice is entrenched in experience based learning initiated by Dewey (1938), Vygotsky's (1978) social cognitive theory, and founded in the premise of situated learning. Consequently as envisaged in teacher education in Kenya, teaching practice is meant to provide for the authentic context within which student teachers are exposed to experience the complexities and richness of the reality of being a teacher. This process allows the student teacher an opportunity to establish whether the right career choice has been made or not. However, despite its importance, Kiggundu and Nayimuli (2009) note that teaching practice sometimes becomes a demoralizing and sometimes very frightening experience. It is on this background that this study examines the student teachers' perspective of teaching practice and the challenges faced by student teachers during teaching practice.

\subsection{The purpose of the study}

This study aimed at investigating the real context of teaching practice as experienced by the student teachers of the school of Education at the University of Eldoret and its impact on student teachers perception on the teaching profession. This study further attempted to highlight the challenges that the student teachers face while on teaching practice.

\subsection{Objectives}

The specific objectives of the study were:

(i) To investigate the student teachers' experiences during teaching practice and its impact on their perception of the teaching profession.

(ii) To establish the challenges faced by students teachers during teaching practice

\subsection{The significance of the study}

The significance of this study emerges from the importance of teaching practice experience in Kenyan teacher education programs and its role in teacher preparation. Also this study is vital in that it examines the educational competencies of student teachers, and its ability to diagnose the challenges faced by student teachers during teaching practice. Furthermore, the results of this study may draw attention to several problems and challenges faced by the student teachers while in the field. Therefore, this study attempts to share these issues that may help the educational stakeholders to minimize these challenges and its impact and to facilitate the training process to achieve the goals of teaching practice for prospective student teachers and understand their perspectives towards the teaching profession.

\subsection{Literature review}

\section{What is teaching practice?}

Marais \&Meier (2004:221) assert that the term teaching practice represents the range of experiences to which student teachers are exposed when they work in classrooms and schools. According to Emerole (2000), the term teaching practice is an experience of guided teaching in which the trainee teacher assumes increased responsibility for directing the learning of a group for over a period of time. Imart (2003) explains that, the term teaching practice has three major connotations the practicing of teaching 
skills and acquisition of the role of a teacher, the whole range of experiences and practical aspects of the course as distinct from theoretical studies. Teaching practice is the name of the preparation of student teachers for teaching by practical training. Andabai (2011) posits that, it is the practical use of teaching principles, teaching techniques and practical training/practical exercise of different activities of daily school life. Hassan (2000) further asserts that, it is a period which provides opportunities under typical school conditions in selected cooperating schools for trainee teachers to secure experience in observing and participating actively in diverse educational activities of teaching in the school. McGee and Fraser (2001) emphasize that it is in teaching practice that student teachers are baptized with the experience to gain knowledge of how teachers go about the many and complex task involved in actual classroom practice. All these definitions indicate that the teaching practice is a vital exercise that provides the opportunity to beginning teachers to become socialized into the profession.

In Kenya teaching practice is an essential aspect of teacher education because it prepares teachers for their future teaching roles and assignment. During teaching practice, the trainee teachers are sent out from the University to primary, secondary, commercial, and technical schools to teach for a period of three months as a part of their training. During this practice a student teacher is supervised and evaluated not only by a supervisor allotted to him/her but also by a group of other lectures who supervise the student teachers and the collaborating teacher. Akpomi (2001) argues that, the need for this different evaluation is to make sure that the student teacher is properly corrected and graded.

\subsection{The strengths of teaching practice}

Teaching practice has attracted many researchers and most of the findings show that teaching practice has more strengths than weaknesses. Some of the strengths that have been established by researchers are that: It grants student teachers experience in the actual teaching and learning environment (Marais \&Meier, 2004:220; Perry, 2004:2). Teaching practice enables student teachers to understand the real world of teaching and let them know about problems and difficulties of teaching that may face them in the future.Hence, student teachers understand their students' environment and accept students' diversity. Moreover, teaching practice enables the student teacher transit from the role of students to the role of beginning teachers. Kasanda, (1995) indicates that during teaching practice, a student teacher is given the opportunity to try the art of teaching before actually getting into the real world of the teaching profession. Thus they develop their professional and personal competencies. Student teachers also know the value of teaching practice and as remarked by Menter (1989: 461) they perceive it as 'the crux of their preparation for the teaching profession since it provides for the real interface between student hood and membership of the profession. As a result, teaching practice creates a mixture of anticipation, anxiety, excitement and apprehension in the student teachers as they commence their teaching practice (Perry, 2004:4). Furthermore, Ajoku (2003) established that performance during teaching practice provides some basis for predicting the future success of the teacher and the quality of teacher education programs. Edem (2003) explains that, during teaching practice, working with students in schools provide a high degree of emotional involvement of a mostly positive nature. Students teachers feel that they grow through experience and they begin to link to the culture of teaching. In this case student teachers develop a positive attitude towards the profession and the students. Edem (2003) further asserts that, during teaching practice, student teachers feel engaged, challenged and even empowered. In another study, Osuala (2004) established that, teaching practice exposes the trainee teacher to the realities of effective teaching and helps them to try out methods of teaching and gain practical classroom experience under experts. Itejere (1998) stressed this aspect and stated that teaching practice is the most vital part of trainee teacher's career training, this is because it is during this practice that the trainee teachers applies the methods, even the philosophy of education which he/she was taught theoretically in the classroom. Thus it plays a key role in bridging the gap between theory and practice. As it is commonly said that "theory without practice is empty; practice without theory is blind"(Morrison \&Werf, 2012, p.1). The teacher trainee realizes his/her professional responsibility as a teacher and starts to learn how to manage the younger ones who 
are left under his/her control and care. According to Tuli and File (2009) teaching practice allows student teachers to discover their abilities and creativities that help them in their future teaching processes.

\subsection{The challenges that students experience during teaching practice}

Marais and Meier (2004:221) argue that teaching practice is a challenging but important part of teacher training, especially in developing countries. Kenya as a developing country is not an exception and student teachers encounter challenges during teaching practice. Studies done in Zambia and South Africa show the following challenges that student teachers encounter during teaching practice; inadequate preparation of the student teachers, geographical distance, low and uneven levels of teacher expertise, a wide ranging lack of resources as well as a lack of discipline among a wide cross section of learners and educators, lack of finances and accommodation facilities, non involvement in other school activities, very little support and lack of trust from the cooperating teachers and lack of clear policies that govern teaching practice (Kasanda 1995, Kiggundu and Nayimuli 2009). These challenges, if not addressed, may affect student teachers' performance during teaching practice and may in the long run affect their perception of the teaching profession. Yassin (2004) studied the problems faced by the students at the Faculty of Education in Gaza during their teaching practice and established the following: the long distance between the assigned schools and the students' houses, the lack of guidance provided by school principals regarding the school systems, regulations and the participation in the school activities, and the lack of respect showed from the cooperating teachers towards student teachers. Yassin (2004) further studied the challenges from academic supervisors during teaching practice and established that the academic supervisors do not hold regular meetings with student teachers to discuss the challenges that face them. In addition, student teachers do not find adequate encouragement from the academic supervisors for their work, also they do not find adequate assistance in getting textbooks and teachers' guides from their collaborating teachers and did not receive adequate explanation of the required skills, and did not get appropriate guidance to motivate them to implement classroom activities.

Bechuke et al (2013) while investigating the challenges that student teachers encounter during teaching practice in South Africa revealed that most mentors are not well informed of their responsibilities as mentors to student teachers during teaching practice. Mentors consider their responsibility as being a university assignment to supervise. Moreover, the findings indicated that mentors lack training to function as mentors to student teachers during teaching practice.

Bechuke et al (2013) further revealed that university assessors are not consistent in their duties as supervisors. They state that lecturer supervisors from the university do not pay regular visits to practicing schools and that some student teachers indicated that they were never visited by university assessors, not even once, and yet their visits and roles contribute heavily to the success of the practice. In Africa, most student teachers undertake their practice in remote areas which are a far distance from the university. The impact of the location of these schools on teaching practice is that those student teachers are never assessed by university lecturers and if they are assed it is only once. Apart from lecturers not assessing student teachers in distant schools, other potential dangers in these schools include lack of human resources to train these student teachers as expected by the programme. Also some of these schools are understaffed and lack adequate infrastructure. With all these disadvantages in some of these schools, the objectives of teaching practice are not achieved and this paper sought to establish some of the challenges that Kenyan university students encounter during teaching practice.

\subsection{Methodology}

The study adopted the survey design where by questionnaires were used to collect data from 100 randomly selected third year students from the university of Eldoret who had completed teaching practice. The sample was composed of 50 male and 50 female students. The students were asked to answer the 30 questions on the questionnaire. The questionnaire was used to test the student teachers' perspective of 
teaching practice and the challenges faced by student teachers during teaching practice. A five-point likert scale was used.

\subsection{Discussion of the findings}

\section{1: The student teachers' perspective of teaching practice}

From Table 1 we can see that, out of the responses collected from the respondents, question 1-15 had majority of the students selecting strongly agree or agree and very few students disagreed with the given statements. This indicates that teaching practice gave the students a number of experiences and these experiences had an impact on their perceptions on the teaching profession. Teaching practice has been found to be very beneficial in the course of this research work because, it provides an opportunity for the trainee teachers to teach and increase their professional competence. The result showed that trainee teachers benefited greatly in participating in teaching practice because they were able to decide whether or not to take to teaching as a profession, they got the opportunity to try out ideas and theories in a practical classroom situation, they developed interest of teaching and were exposed to the problems and prospects of the teaching profession, they learnt to plan, prepare and present lesson topics appropriately. Teaching practice helped them to acquire those valuable personality attributes that are associated with an outstanding teacher and to perfectly use instructional materials when teaching. In addition, they stated that teaching practice is a vital factor in preparing them for future teaching assignment since it helped them to learn to use reinforcement and assessment skills correctly. Student teachers also indicated that they gained general experience in the teaching profession and got the opportunity to communicate and interact closely with learners and control the class effectively. Generally the student teachers indicated that they were able to build proper confidence and competence in lesson preparation and developed skills and attitudes of a teacher during the exercise. It was also revealed that teaching practice helps trainee teachers to learn how to keep records of assignment and also to participate in school activities. They further were able to master professional skills and broaden their knowledge of the subject matter.

Table 1: The student teachers' perspective of teaching practice

\begin{tabular}{|l|l|l|l|l|l|l|l|}
\hline & Statement & SA & A & UD & D & SD & Remark \\
\hline 1 & $\begin{array}{l}\text { Teaching practice has made me to decide whether or not to } \\
\text { take to teaching as a profession }\end{array}$ & 35 & 5 & 5 & & Agree \\
\hline 2 & $\begin{array}{l}\text { Teaching practice gave me an opportunity to try out ideas } \\
\text { and theories in a practical classroom situation. }\end{array}$ & 60 & 40 & & & Agree \\
\hline 3 & Teaching practice developed in me the interest of teaching & 45 & 50 & 2 & 3 & & Agree \\
\hline 4 & Teaching practice has made me to master professional skills & 70 & 28 & 2 & & & Agree \\
\hline 5 & $\begin{array}{l}\text { Teaching practice has exposed me to the problems } \\
\text { and prospects of the teaching profession }\end{array}$ & 40 & 54 & 3 & 3 & & Agree \\
\hline 6 & $\begin{array}{l}\text { Teaching practice helped me to broaden my knowledge of } \\
\text { the subject matter }\end{array}$ & 80 & 20 & & & Agree \\
\hline 7 & $\begin{array}{l}\text { Teaching practice has made me to learn how to plan, } \\
\text { prepare and present my lesson topics appropriately }\end{array}$ & 67 & 32 & 1 & & & Agree \\
\hline 8 & $\begin{array}{l}\text { Teaching practice has helped me to acquire those valuable } \\
\text { personality attributes that are associated with an outstanding } \\
\text { teacher. }\end{array}$ & 32 & 62 & 2 & 3 & 1 & Agree \\
\hline 9 & $\begin{array}{l}\text { Teaching practice has helped me to perfectly use } \\
\text { instructional materials when teaching. }\end{array}$ & 82 & 18 & & & & Agree \\
\hline 10 & $\begin{array}{l}\text { Teaching practice has helped me learn to use reinforcement } \\
\text { and assessment skills correctly }\end{array}$ & 83 & 16 & 1 & & & Agree \\
\hline
\end{tabular}




\begin{tabular}{|c|l|l|l|l|l|l|l|}
\hline 11 & $\begin{array}{l}\text { Student teachers see teaching practice as a vital factor in } \\
\text { preparing them for future teaching assignment. }\end{array}$ & 68 & 1 & & Agree \\
\hline 12 & $\begin{array}{l}\text { Teaching practices has enabled student teachers to gain } \\
\text { general experience in the teaching profession. }\end{array}$ & 47 & 48 & 1 & 4 & Agree \\
\hline 13 & $\begin{array}{l}\text { Teaching practice has given me the opportunity to relate my } \\
\text { studies to my future career. }\end{array}$ & 82 & 18 & & & Agree \\
\hline 14 & $\begin{array}{l}\text { Teaching practice gave me an opportunity to communicate } \\
\text { and interact closely with learners and control the class } \\
\text { effectively }\end{array}$ & 46 & 41 & 3 & Agree \\
\hline 15 & $\begin{array}{l}\text { Teaching practice helped me to develop my own way of } \\
\text { working effectively with learners and colleagues }\end{array}$ & 44 & 53 & 1 & 2 & & Agree \\
\hline
\end{tabular}

\section{2: The challenges student teachers' experience during teaching practice}

The study also sought to establish the challenges that student teachers experience during teaching practice. The findings on Table 2 indicate that student teachers experience quite a number of challenges. These challenges were seen as geographical, administrative, professional, instructional, supervision, social and financial. On geographical challenges, majority of the student teachers indicated that they walk for a long distance to the school and the roads are impassable and more so they face accommodation problems in the schools they were posted to. On administrative issues the student teachers stated that some schools reject student teachers Students, while others stated that they were given more lessons as required in the university regulations and that student teachers were not fully involved in all school activities and were not allowed to interact with the permanent teacher as they were in some cases assigned a different staffroom. Concerning professional challenges the student teachers indicated that in some schools, teaching staff hoard professional advice from trainee teachers and in other cases student teachers are overloaded by the cooperating teachers by being assigned some of their duties. On instructional challenges the research established that some schools lack instructional materials that are needed for effective teaching. The challenges on supervision were that supervision was not done regularly and uniformly and also it was noted that the student teachers stated that the supervisors were harsh and not friendly. In the social perspective the student teachers showed that school students do not respect student teachers and student teachers met some rudely behaved students and they have very little control over them. Moreover financial challenges were established since the student teachers indicated that they faced financial challenges during teaching practice in that majority of them stated that they lacked finances for their up keep.

Table 2: The challenges student teachers' experience during teaching practice

\begin{tabular}{|l|l|l|l|l|l|l|l|}
\hline & Statement & SA & A & UD & SD & D & Remarks \\
\hline 1 & Some schools reject student teachers & 43 & 35 & 2 & 12 & 8 & Agree \\
\hline 2 & $\begin{array}{l}\text { Permanent teachers are not friendly and do not want to } \\
\text { interact with student teachers }\end{array}$ & 45 & 41 & & 9 & 5 & Agree \\
\hline 3 & $\begin{array}{l}\text { In some schools, teaching staff hoard professional } \\
\text { advice from trainee teachers }\end{array}$ & 38 & 36 & 1 & 15 & 10 & Agree \\
\hline 4 & $\begin{array}{l}\text { Student teachers face accommodation problems in the } \\
\text { schools they have been posted to }\end{array}$ & 35 & 30 & & 20 & 15 & Agree \\
\hline 5 & $\begin{array}{l}\text { Some schools lack instructional materials that are } \\
\text { needed for effective teaching }\end{array}$ & 70 & 25 & & 5 & & Agree \\
\hline
\end{tabular}




\begin{tabular}{|l|l|l|l|l|l|l|l|}
\hline 6 & $\begin{array}{l}\text { Students teachers are given more lessons as required in } \\
\text { the university regulations }\end{array}$ & 36 & 19 & & 27 & 18 & Agree \\
\hline 7 & $\begin{array}{l}\text { Student teachers meet some rudely behaved Student } \\
\text { and they have very little control over them }\end{array}$ & 55 & 40 & & 5 & & Agree \\
\hline 8 & School students do not respect student teachers & 46 & 34 & & 15 & 5 & Agree \\
\hline 9 & $\begin{array}{l}\text { Student teachers are not fully involved in all school } \\
\text { activities }\end{array}$ & 36 & 38 & & 18 & 8 & Agree \\
\hline 10 & $\begin{array}{l}\text { Student teachers are overloaded by the cooperating } \\
\text { teachers by being assigned some of their duties }\end{array}$ & 58 & 31 & 1 & 10 & & Agree \\
\hline 11 & $\begin{array}{l}\text { Some of the student teachers lack finances for personal } \\
\text { up keep }\end{array}$ & 70 & 28 & & 2 & & Agree \\
\hline 12 & $\begin{array}{l}\text { Student teachers are not allowed to interact with the } \\
\text { permanent teacher and are even assigned a different } \\
\text { staffroom }\end{array}$ & 53 & 23 & 2 & 8 & 14 & Agree \\
\hline 13 & $\begin{array}{l}\text { Student teachers walk for a long distance to the school } \\
\text { and the roads are impassable }\end{array}$ & 35 & 32 & 2 & 18 & 13 & Agree \\
\hline 14 & Supervision was not regularly and uniformly done & 70 & 25 & & 5 & & Agree \\
\hline 15 & Supervisors are harsh and un friendly & 80 & 20 & & & & Agree \\
\hline
\end{tabular}

\subsection{Conclusion and Recommendations}

From the findings of this study the following conclusions were done:

(i) That the student teachers' perspective of teaching practice is positive in that the student teachers found teaching practice to be very beneficial and it provided an opportunity for the trainee teachers to increase their professional competence.

(ii) Also student teachers faced challenges during teaching practice

\section{2: Recommendations}

Based on the findings of the study, the following recommendations were made:

(i) Schools of education and colleges should organize the teaching practice exercise very well so as to give the best professional practice to the trainee teachers.

(ii) A proper orientation for student teachers should be carried out using efficient means of communication like; seminars, workshops, conferences and discussion before they go for teaching practice.

(iii) Student teachers should participate at least once or twice in micro-teaching exercises as a way of exposing them to teaching practice.

(iv) The university should appeal to the government, non-governmental organizations like the private sector, individuals and industries to assist in supplementing educational materials and learning resource that would prepare the students teachers.

(v) The cooperating teachers should be trained on their roles while working with the student teachers.

(vi) The government should provide finance inform of stipend for student teachers so as to boost their up keep and their attitude towards the profession.

(vii) The university should train the supervisors and supervision of students while on teaching practice should be done professionally. 


\section{References}

Andabai, P. W. (2010). Learning, Organizational Learning and the Learning Organization: Concept, Theories and Models. Journal of Knowledge Management. Vol. 1 No. 2.

Ajoku, L. I. and Achuonye, K. A. (2003). Foundations of curriculum: Development and implementation. Port Harcourt. Pearl Publishers.

Akpomi, M. E. (2001). Organizing Business Education. Port Harcourt: Pre Joe Ventures.

Bechuke, A. L., Thomas, E. B. A. and James D. (2013).Teaching Practice for the $21^{\text {st }}$ Century: Challenges and Prospects for Teacher Education in the North-West Province, South Africa. J Soc Sci, 37(3): 279-291 (2013.

Broadbent, C. 1998. Pre-service students' perceptions and level of satisfaction with their field experience. Asia-Pacific Journal of Teacher Education, 26(1): 27-37.

Cohen, I, Manion, L, Morrison K. (1996). A Guide to Teaching Practice. London: Routledge Falmer

Dewey, (1938). Experience and Education. New York: Collier.

Edem, D. A. (2003). Introduction to Educational Administration in Nigeria. Onitsha: Leotina Nigeria Ltd

Emereole, H. U. (2000). Problems associated with teaching in Rivers State of Nigeria. A journal of technical and science education.

Ezewu, E.E, Okoye, N, Onyekwelu, V.C. (1994). Student Teachers' Handbook for Teaching Practice. Nigeria: MacMillan

Haigh, M. (2001). Coherence and Congruence of Perceived Roles within Practicum Partnerships. A Case Study Paper Presented at the New Zealand Association for Research in Education Annual Conference, Christ church, New Zealand. December 6-9, 2001

Imart, J. (2003). Two Basic Mechanisms for Organizational Learning in Schools. European Journal of teacher education, Vol. 36, No. 3.

Itejere, P. O. (1998). Teachers Preparation and Professionization of Teaching in Nigeria: The way Forward. A lecture delivered on $13^{\text {th }}$ November on the occasion of NTI Matriculation Ceremony at Baptist High School, Eku.

Kasanda, C.D. (1995). Teaching practice at the University of Namibia: Views from student teachers. Zimbabwe Journal of Educational Research, 7:57-68.

Kiggundu, E. and Nayimuli, S (2009). Teaching Practice: A Make or Break Phase for Student Teachers. South African journal of Education Vol. 29:345-358.

Koko, M. N. (2002). Organizational Behaviour: Concept and Dimension. Bengray Publishing Company. Port Harcourt

Lave, J. \&Wenger E. (1991). Situated learning. New York: Cambridge University.

Marais, P. \& Meier C. (2004). Hear our voices: student teacher's experience during practical teaching. Africa Education Review, 1:220-233.

Menter, I. (1989).Teaching Stasis: Racism, sexism and school experience in initial teacher education. British Journal of Sociology of Education, 10:459-473.

McGee, C, and Fraser, D. (2001). The Professional Practice of Teaching. Palmerston North: Dunmore Press.

Morrison, K., \&Werf, G. (2012). Educational Research and Evaluation: An International Journal on Theory and Practice. Educational Research and Evaluation. 18, 5 (3099-401).

Perry, R. (2004). Teaching practice for early childhood. A guide for students. Retrieved from http://wwwRoutledge.comcatalogues./0418114838.pdf

Tuli, F. \&File, G. (2009).Practicum experience in teacher education, Ethiopia Journal of education and sciences, 5(1), 107-106

Osuala, E. C. (2004). Principles and Methods of Business and Computer Education. Enugu: Cheston Agency Ltd.

Samuel, M. (2010). Searching for a "Pedagogy of Hope": Teacher education and social sciences. Perspectives in Education, 28(1): 5-15 
Yassin, R. (2004). The development of practicum program at the University of l-Aqsa by using systems analysis. (Unpublished Ph.D. thesis), Faculty of Education, Al-Aqsa University, Gaza

Vygotsky, L. (1978). Mind in Society: The development of higher psychological processes. Cambridge: Harvard University Press 